\title{
Irakificering: \\ Vejen mod afgrunden?
}

Derek Beach

\section{Problemerne i Irak forsvinder ikke ved at de} amerikanske eller andre udenlandske tropper bliver trukket ud. Tværtimod ligner den nuværende “irakificerings"-strategi en sikker opskrift på en blodig borgerkrig

Kan koalitionen trække sig ud af Irak på en måde som er i overensstemmelse med formålene om demokratisering og genopbygning af Irak? Den nuværende exit-strategi kaldes "irakificering". Håbet er at det irakiske demokrati, efter to demokratiske valg og en folkeafstemning om forfatningen, vil være så rodfæstet, at irakerne kan stå på egne ben. Koalitionen har til opgave at træne det irakiske politi og militær til selv at klare sikkerhedsopgaverne i Irak, så at en tilbagetrækning af koalitionens tropper inden for en kortere årrække vil være mulig.

Men er denne "irakificering" en holdbar strategi, og kan irakerne selv føre landet igennem den demokratiske transitionsproces hen imod opbygningen af et stabilt og konsoli- deret demokrati? Eller vil "irakificering" gøre ondt værre med det resultat, at den irakiske demokratiseringsproces bliver afsporet og øger risikoen for en blodig borgerkrig eller for at et nyt diktatur opstår?

Historien gentager sig aldrig, men erfaringer fra andre demokratiske transitionsprocesser kan give os et kvalificeret svar på disse spørgsmål. Belært af historiske erfaringer ved vi, at demokratisering er meget svært med mange faldgruber undervejs. Og stater hvor transitionen er mislykkedes er tit farligere for både deres egne borgere og nabo-staterne end både konsoliderede demokratier og autoritære styrer. Desuden betyder træningen af politi og militær i Irak, at den ene part i en sekterisk konflikt bliver styrket, hvor- 
ved man risikerer at hælde yderligere benzin på bålet.

Det mest sandsynlige scenario vil være, at den irakiske transition vil køre helt af sporet, hvis koalitionen forsætter den nuværende "irakificerings"-strategi. Det mest sandsynlige resultat efter at de udenlandske tropper er trukket ud vil være, at landet havner enten i den frygtede blodige borgerkrig med dertilhørende etniske udrensninger og folkemord eller får et nyt diktatur.

I det følgende vil jeg diskutere problemerne med "irakificering" med fokus på problemerne omkring de to grundlæggende antagelser, som strategien bygger på: 1) demokratisering er forholdsvis nemt; og 2) de udenlandske tropper i Irak er årsag til oprøret, og hvis man overdrager ansvaret for sikkerheden til irakiske tropper, så fjerner man årsagen til konflikten i Irak. I konklusionen vil jeg diskutere alternative strategier for koalitionen i Irak.

\section{Er demokratisering nemt?}

For det første, demokrati opstår ikke bare fordi man afholder demokratiske valg. De neokonservative i USA antog, at demokrati er "normalen", og hvis man fjerner et autoritært styre, vil der nærmest per automatik opstå et demokrati. Men kommer demokrati spontant, eller er det en langstrakt og besværlig proces med mange faldgruber undervejs?

De første demokratiske valg er al- tid festlige. Men det er en langt, langt vanskeligere og langstrakt proces at føre det unge politiske demokrati igennem alle de fristelser og faldgruber systemet og dets magthavere møder på vejen mod at blive et modent, funktionelt demokrati. Der er mange grunde til at ud af de 85 lande som påbegyndte demokratiseringen efter 1974, er det kun omkring 30, der er blevet stabile og konsoliderede demokratier (Geddes, 1999, "What do we know about democratization after twenty years?", Annual Review of Political Science, 1999, s. 115-144). Størsteparten af de lande der forsøger at bliver demokratier havner i grøften - noget som fx kan iagttages i disse år i Rusland.

Unge demokratier har ikke de demokratiske institutioner, der kan sikre, at de nye politiske ledere spiller efter reglerne. Demokrati går i sidste instans ud på, at stærke institutionaliserede regler og normer kan sikre, at de grupper som "vinder" de politiske kampe ikke udnytter magtens privilegier alt for groft, samt at de "tabende" gruppers rettigheder respekteres, så de har mulighed for igennem deltagelsen i en politisk proces at blive den "vindende" part.

Demokratier i transition er skrøbelige, da de nye magthavere støder på mange "fristelser" til at misbruge deres magtbeføjelser. Nye demokratiske regimer mangler den legitimitet som konsoliderede de- 
mokratiske regimer har, og de er ofte udsat for politisk ustabilitet og udfordringer fra konkurrerende grupper. Derfor har de nye politiske ledere ofte interesse i at udnytte deres position til at skrive de politiske spilleregler på en måde, der sikrer deres position, og hvor mindretal og modstandere er permanent udelukket.

Grundlæggende skal demokratier have spilleregler der sikrer, at mindretal også har muligheder for politisk indflydelse, og evt. kan blive den "vindende" part, hvilket sker i velfungerende føderale systemer som USA og Tyskland, hvor fx små delstater er overrepræsenteret i de føderale beslutningsorganer. Det vi har set i Irak indtil nu er desværre, at det shiitiske flertal har udnyttet deres nye dominerende position til at lave en forfatning der reelt marginaliserer og permanent udelukker det sunni-muslimske mindretal fra indflydelse på føderalt niveau.

Nye eliter i transitionsdemokratier står også over for stærke fristelser til at misbruge militær og politi både mod interne modstandere og eksternt mod andre stater. Forskning viser, at lande i transition ofte er mere tilbøjelige til at bruge undertrykkende metoder mod deres egen befolkning og bekrige nabostater end både demokratier og autoritære styre.

Risiko for misbrug af magt er paradoksalt størst i starten af demokratisk transition. Politikere i unge demokratier har ikke veletablerede vælgerkredse, men er i stedet kastet ud i en hård kamp om stemmer. Her er det let at forfalde til populistiske "tricks" som at spille på etniske, religiøse eller nationale forskelle for at vinde stemmer. Desværre mangler unge demokratier stærke politiske institutioner, der kan sikre at populisme ikke fører til, at transitionen bliver afsporet. Et godt eksempel herpå var det første valg $\mathrm{i}$ Bosnien i starten af 1990'erne, hvor politikerne spillede på etniske og religiøse forskelle med det resultat, at de cementerede og forstærkede de etniske og religiøse konfliktlinjer og førte landet ud i en borgerkrig. Et andet eksempel er Serbien, hvor Milosevics nationalistiske retorik førte til krige mod Kroatien, indblanding i Bosnien, og misbrug af politi og militær mod interne mindretalsgrupper (fx Kosovo-albanere).

Det ser desværre ud til, at misbrug af både politi og militær er ved at løbe løbsk i Irak - især efter bombningen af moskeen i Samarra d. 22. februar 2006. Da USA gav efter over for shiitisk pres, blev der afholdt to valg i 2005. Men meget tyder på, at disse valg blev afholdt for tidligt og yderligere har cementeret og forstærket de etniske og religiøse konflikter i Irak. Situationen i Irak er i skrivende stund tæt på en borgerkrigslignende sekterisk konflikt mellem den shiitisk dominerede regering støttet af kurderne og et marginaliseret sunni-mindretal.

Rapporter fortæller, hvordan det 
irakiske politi og militær i stigende grad bruges til at undertrykke, torturere og dræbe det marginaliserede sunni-mindretal. Stærke militser fra shiitiske partier som SCIRI og Sadr's "kontoret for martyren Sadr" har infiltreret politiet og militæret og i mange tilfælde overtaget "opgaver" fra de ordinære styrker. Amerikanske styrker har fundet flere hemmelige politiske fængsler, der er drevet af indenrigsministeriet, og hvor sunni-muslimer er blevet tortureret af shiitisk "politi" og "militære" styrker. Der er også troværdige rapporter om dødspatruljer, hvor sunni-muslimer bliver bortført og dræbt af shiitiske sikkerhedsstyrker.

Konklusionen er, at demokratisering er ikke nemt, men ofte stiller nye politiske ledere over for næsten umenneskelige fristelser. Risikoen for at den irakiske demokratiseringsproces kører af sporet er endnu større pga. følgende tre faktorer. For det første, demokratisering er ikke så meget et indre som et ydre pres, hvilket betyder, at der ikke er stærke interne kræfter, der kan bringe det irakiske demokrati tilbage på sporet. Irak mangler især den stærke middelklasse, der var en af drivkræfterne bag konsolideringen af demokrati i lande som Sydkorea og Taiwan. For det andet er det aldrig lykkedes for et land at blive et konsolideret demokrati samtidig med, at det bekæmpede en stærk intern trussel i form af et oprør/borgerkrig. Irak kan måske blive det første land der bryder dette mønster, men en dårlig sikkerhedssituation samt bekæmpelsen af interne grupper med militær magt må antages at have stærke negative effekter for sundheden af det politiske system i et ungt demokrati. Endelig er der arven fra diktaturtiden, hvilke betyder, at de demokratiske normer om fredelig løsning af politiske konflikter simpelthen ikke er til stede i Irak i dag.

\section{Benzin på bålet}

"Irakificerings"-strategien bunder i en grundlæggende misforståelse af, hvad konflikten i Irak drejer sig om. Ifølge Bush-regeringen handler konflikten i Irak om at bekæmpe et oprør bestående af udenlandske jihadister og Saddam-loyalister, som i et sidste desperat forsøg, før de er endeligt nedkæmpet, forsøger at skabe en borgerkrig. Men Bush-regeringen har fejlfortolket konfliktens årsager siden invasionen i marts 2003.

Konflikten i Irak ligner i stigende grad en forudsigelig sekterisk borgerkrig mellem det nye shiitiske flertalsstyre og et marginaliseret sunnimindretal. Alt tyder på at det meste af den vold, der er i Irak, i stigende grad skyldes denne sekteriske konflikt og ikke koalitionens tilstedeværelse. Volden bliver kun rettet mod koalitionen, når den forsøger at nedkæmpe de to parter. Dette forklarer også, hvorfor der ikke er særlig meget vold rettet mod de bri- 
tiske og danske styrker, der er stationeret uden for "borgerkrigszonen".

Når koalitionen træner irakiske sikkerhedsstyrker, støtter man den ene part i denne sekteriske konflikt. Som beskrevet ovenfor kontrollerer den ene part i borgerkrigen både politiet og militæret dog med undtagelse af de kurdiske områder. En del politi- og militærenheder er kontrolleret af shiitiske militser, og de fleste af de ikke-infiltrerede enheder består udelukkende af shiitter. Koalitionen har forsøgt og forsøger at sørge for en bedre repræsentation af sunni'er i politiet og militæret, men disse forsøg er hidtil mislykkedes.

Derfor styrker træningen og styrkelsen af det irakiske politi og militær i virkelighed den stærke part i konflikten om magtfordeling i Irak. Dette vil gøre det nemmere for shiiterne at opnå deres mål ved magt $\mathrm{i}$ stedet for at indgå i en politisk dialog med sunni-mindretallet, hvilket også vil øge sandsynligheden for, at Irak kastes ud i en borgerkrig.

Desuden risikerer man at puste yderligere til ilden ved at overdrage ansvaret for "sikkerheden" i Irak til det shiitisk-kontrollerede politi og militær. Det vil så ikke længere være udenlandske tropper som bekæmper den ene part, men i stigende grad være en åben konflikt mellem shiitiske sikkerhedsstyrker og sunnioprørsstyrker. Med andre ord, overdragelse af ansvaret for "sikkerhed" burde forstås som om koalitionen overdrager ansvaret til shiitterne for at nedkæmpe sunni-oprøret mod det nye shiitiske flertalsstyre.

Styrkes militæret, er der en meget stærk risiko for at det irakiske "demokrati" vil blive undermineret. Man risikerer latinamerikanske tilstande, hvor svage politiske institutioner ikke er i stand til at kontrollere militæret med det resultat, at militæret i stigende grad bliver en aktør i det politiske system.

\section{Konklusion}

Det har hele tiden været utopisk at tro, at koalitionen ville være i stand til at skabe et liberalt og konsolideret demokrati i Irak under så svære omstændigheder. Det har været en misforståelse at sammenligne Irak med Japan og Tyskland, da disse lande både havde homogene befolkninger med en middelklasse og var udsat for en stærk ekstern trussel som gjorde, at de amerikanske styrker blev set som beskyttere og ikke besættere.

Resultatet bliver højst sandsynligt, at Irak med den nuværende "irakificerings"-strategi vil havne i grøften, og ender ud i enten en borgerkrig eller et nyt diktatur. Historien viser demokratiets svære kunst, og at lande i transition tit er farligere for både deres egen befolkning og deres omgivelser end et konsolideret demokrati og eller autoritært styre. Koalitionen burde derfor have forberedt sig på en langvarig besættelse af Irak for at sikre sig, at landets 
transitionsproces ikke blev afsporet.

Træning af politi og militær samt overdragelse af "sikkerheds"opgaver svarer i virkeligheden til at hælde mere benzin på bålet. Herved styrker man den ene part i en sekterisk borgerkrig og giver den i stigende grad ansvaret for at nedkæmpe den anden part i en borgerkrig.

Hvis ikke det allerede er for sent, så burde koalitionen gå væk fra "irakificerings"-strategien og i stedet anvende en politisk strategi, som forsøger at løse den underliggende konflikt i Irak. Koalitionen skal sætte hårdt mod hårdt over for shiitterne. Shiitterne er stadigvæk afhængige af, at koalitionen laver deres "beskidte arbejde", dvs. nedkæmper sunni-oprøret. Derfor skal koalitionen spille dette kort over for shiitterne for at få ændret forfatningen i retning af en mere fair fordeling af magten. Et bud på dette kunne være en overrepræsentation af sunnierne i parlamentet; enten ved at indføre et tokammersystem som i USA eller et system, hvor de små er overrepræsenteret, som man ser det i Ministerrådet i EU.

Det er måske allerede for sent at lave andet end kosmetiske ændringer til forfatningen. Det mest realistisk alternativ til "irakificering" og dertilhørende borgerkrig eller diktatur vil for koalitionen nok være at skifte til, hvad man kan kalde en "bosnificerings"-strategi. I Bosnien har man accepteret, at de underliggende konfliktlinjer mellem de etniske/religiøse grupper er så stærke, at det eneste alternativ til enten en opsplitning af landet eller en ny borgerkrig er, at udenlandske tropper sørger for at holde grupperne adskilt i en meget decentral føderal stat. 11 år efter borgerkrigens ophør er der stadig 7.000 udenlandske tropper i Bosnien.

En lignende strategi er måske det mest realistiske alternativ i Irak til enten borgerkrig, diktatur eller opsplitning. Men skal "bosnificering" anvendes i Irak, kræver det tilstedeværelse af mange udenlandske tropper i mange år (45.000 om 11 år hvis det skal svare til Bosnien), og det er langt fra sikkert, at regeringerne i koalitionslandene kan overhøre det stigende politiske pres for at trække tropperne hjem.

Der er ingen lette løsningen når det gælder Irak, og problemet forsvinder ikke bare fordi de danske og andre udenlandske tropper bliver trukket ud. Desværre ligner den nuværende "irakificerings"-strategi en sikker opskrift på en blodig borgerkrig i Irak, hvor koalitionen vil have et medansvar, da den har trænet og styrket den ene part i krigen.

Derek Beach er lektor i international politik, Århus Universitet 